\title{
Epilogue - The ICC On the Yellow Brick Road
}

\author{
Antonio Coco* and Matthew E. Cross**
}

In the legendary 1939 movie, after landing with her house in the magical land of Oz, Dorothy Gale exclaimed 'Toto, I have a feeling we are not in Kansas anymore!' with a mix of disillusionment and curiosity. She was immediately confronted with an unfamiliar reality, threats to her life and great responsibilities. The events of the story pushed her, then, to a yellow brick road leading to The Emerald City, where she would have to find a powerful wizard who could help her to get back home.

Similarly, at its 15 th birthday, the International Criminal Court (ICC) is experiencing a phase of its life where restless weariness and even perhaps a touch of disillusionment pair with the necessity to continue walking on the path open ahead, in the hope of eventually finding the solution to its problems. These problems have been many, including alleged selectivity of action, perceived bias, lack of resources, inefficient use of available resources, lack of cooperation, and accusations of political subservience.

The practice of adopting and publishing policy documents - the subject of this special issue - may seem to have been developed, inter alia, to respond to continuous criticism about the Court's activities, and especially about the choices made by the ICC Office of the Prosecutor (OTP). Correctly or not, the men and women working with the Court's various organs may have thought that increasing the transparency of their decisionmaking process would help the institution in its eternal quest for legitimacy. ${ }^{1}$ However, whilst policy documents are an extremely useful tool, and their timely release can help the Court improve the quality of its work and affect public perception, they are not likely to

\footnotetext{
* PhD Candidate, University of Geneva; Teaching Assistant, Geneva Academy of International Humanitarian Law and Human Rights; member of the Editorial Committee of the Journal. [cocoantonio01@gmail.com]

** Appeals Counsel, Office of the Prosecutor, ICC; member of the Editorial Committee of the Journal. [matthew.e.cross@gmail.com]

The views expressed herein are those of the authors alone, and do not represent the views of the Office of the Prosecutor, or the ICC.

${ }^{1}$ In the words of David Luban, "[i]nternational criminal justice will always be an extraordinary institution that perpetually needs to persuade the world of its own legitimacy." See D. Luban, 'After the Honeymoon: Reflections on the Current State of International Criminal Justice', 11 Journal of International Criminal Justice (JICJ) (2013) 505-515, at 509.
} 
result in universal acclaim. Indeed, whilst more transparency may well lead to more predictability, it does not necessarily ensure less criticism, too. ${ }^{2}$

With a certain dose of realism, one should remember that all human-driven enterprises - the ICC being no exception - are somehow subject to criticism and that, sometimes, eliminating such criticism altogether is not an option. For instance, in this special issue, Rosenberg explains that critics and defenders of the OTP's prosecutorial choices often speak at cross-purposes, giving diametrically opposed meanings to exactly the same expression (in that case, 'impartiality'). It is impossible for the OTP to apply both meanings of the said expression, to counter critics while at the same time keeping 'defenders' satisfied. ${ }^{3}$ Her views are echoed by Stahn, who — as signposted in the article's title — noted the OTP's uncomfortable position of being unable to meet all conflicting demands. ${ }^{4}$ No matter how much effort the OTP, and the ICC in general, put in trying to motivate and justify their course of action, some criticism will likely always persist. ${ }^{5}$

Nonetheless, when facing such criticism, the ICC should resist the temptation of looking at it with either arrogance or despair. ${ }^{6}$ Arrogance, for example, could lead the Court's organs to believe that publicizing policy and strategic documents, which would otherwise remain behind close doors, is a sufficient course of conduct to gain support from public opinion. They could also think that, since these documents contain nothing more than policies, it is possible to depart from them at any time. Quite the contrary, however: the decision not to implement a published policy comes at a price. ${ }^{7}$ As observed by Carayon and O'Donohue with regard to the Court-wide strategy in relation to victims, ${ }^{8}$ even a solid and ambitious policy or strategy can be counterproductive if, in practice, there is a failure to live by it. In this sense, policy and strategic documents create tangible expectations, constituting a

\footnotetext{
${ }^{2}$ D. Robinson, 'Inescapable Dyads: Why the International Criminal Court Cannot Win', 28 Leiden Journal of International Law (2015) 323-347, at 343.

${ }^{3}$ S. Rosenberg, 'The International Criminal Court in Côte d'Ivoire: Impartiality at Stake?', in this special issue.

${ }^{4}$ See also C. Stahn, 'Damned If You Do, Damned If You Don't: Challenges and Critiques of Preliminary Examinations at the ICC', in this special issue.

${ }^{5}$ Robinson, for example, notes that it is not possible to disprove the politicization hypothesis in situation and case selection. See Robinson, supra note 2, at 334-335.

${ }^{6}$ Ibid., at 344 .

${ }^{7}$ As also noted in M. Bergsmo, 'Institutional History, Behaviour and Development', in M. Bergsmo, K. Rackwitz and SONG Tianying (eds.), Historical Origins of International Criminal Law: Volume 5, (Torkel Opsahl Academic EPublisher, 2017) 1-31, at 3, fn 7.

${ }^{8}$ G. Carayon, J. O'Donohue, 'The International Criminal Court's Strategies in Relation to Victims', in this special issue.
} 
wager on the Court's credibility: the reward may be high, should they actually be implemented; the loss may be equally high, should they be disregarded.

On the other side, despair about unrelenting criticism could lead the Court, and the OTP in particular, to lose optimism and faith in its own mandate, settling for more modest results than those envisaged by drafters at Rome. In this regard, Kotecha warns against the risk that the OTP starts behaving more like a private entrepreneur — preoccupied with efficiently managing resources and showing sheer numbers to the Assembly of States Parties - than like an organ of international justice, guided by the desire to achieve precise outcomes in terms of crime prevention and the fight against impunity. ${ }^{9}$

Admittedly, the direction taken with their policy document by the Court, and by the OTP in particular, seems to decrease this 'risk of mediocrity'. ${ }^{10}$ It appears safe to assume that the best way of maximizing the impact of the OTP's activities ${ }^{11}$ is to engage in a transparent and honest dialogue with the stakeholders through dissemination of the said policy and strategic documents. In this sense, authors in this special issue have urged the Court to continue, and even increase, the current trend of dialogue: Pues encourages the Prosecutor to openly acknowledge the extent of its discretion, and to exercise it in a more structured and predictable way; ${ }^{12}$ Varaki advocates for revisiting the OTP's approach to the 'interests of justice' clause in Article 53(1)(c) of the ICC Statute, involving more and more the representatives of affected communities; ${ }^{13}$ Rosenberg advises the Prosecutor to clarify what vision of impartiality she is upholding when conducting investigations and prosecutions; ${ }^{14}$ Kotecha asks the OTP to define more concretely the desired outcomes of its prosecutorial choices, going beyond mere numbers of successful cases. ${ }^{15}$ Whilst — as said at the beginning of this epilogue - insisting on transparent dialogue is no guarantee of a reinvigorated Court which alone will erase atrocities from the planet, it may yet lead the OTP to enhance the quality and credibility of its performance. The institution's success ultimately depends on

\footnotetext{
${ }^{9}$ B. Kotecha, 'The ICC's Office of the Prosecutor and the Limits of Performance Indicators', in this special issue.

${ }^{10} \mathrm{~W}$. Schabas, 'The Banality of International Justice', 11 JICJ (2013) 545-551, at 551.

${ }^{11}$ One of the goals set since the ICC Office of the Prosecutor's 'Report on Prosecutorial Strategy', 14 September 2006, § 2(c).

${ }^{12}$ A. Pues, 'Towards the 'Golden Hour'? A Critical Exploration of the Length of Preliminary Examinations', in this special issue.

${ }^{13}$ M. Varaki, 'Revisiting the 'Interests of Justice' Policy Paper', in this special issue.

${ }^{14}$ Rosenberg, supra note 3.

${ }^{15}$ Kotecha, supra note 9.
} 
this. ${ }^{16}$ More importantly, it may establish the OTP as an exemplar of virtuous behaviour, which could be followed by states in their national proceedings.

In this respect, one of the measures of the Court's success - 50, 100, 200 years from now - may lie in whether it has contributed to advance a sense of global responsibility. ${ }^{17}$ The OTP attitude towards, for instance, victims' participation, sexual and gender-based violence, the 'human factor' in environmental crimes ${ }^{18}$ and matters related to children expressed in the relevant policy papers - reflects an image of the Office as an organ of justice, which champions such global responsibility and, additionally, carries a good part of it. In this special issue, several authors have described the huge impact of OTP's policies on the world outside The Hague: Pues underlined that preliminary examinations (especially if speeded up with a precise time-limit for their completion) can exercise considerable pressure on states to carry out genuine national proceedings; ${ }^{19}$ Rosenberg analysed the enormous significance of ICC investigations for the political balance in Côte d'Ivoire and the country's future,${ }^{20}$ Cusato underlined the great symbolic value of prosecuting environmental crimes, ${ }^{21}$ whose mere possibility — according to Bernaz - may realistically influence business leaders' and corporations' behaviour. ${ }^{22}$ With the OTP's great power, hence, comes the great responsibility of always making reasonable, consistent, and informed choices.

A decade and a half since its establishment, the Court is thus well on its way, like Dorothy on the yellow brick road. If it follows clear and informed strategies, if it keeps being open to dialogue and criticism, if it behaves responsibly, disappointments in the short term which will surely come - may be replaced with at least some measure of satisfaction in the long term. And maybe at the end of the road, very much like Dorothy, the Court too will discover that no deus ex machina will have helped it to get there, if not its own confidence, competence and commitment.

\footnotetext{
${ }^{16}$ With regard to preliminary examinations in particular, see Stahn, supra note 4.

${ }^{17}$ The language was used by Vaclav Havel during an address to the UN General Assembly, cited in A. Cassese, 'Gathering up the Main Threads', in A. Cassese (ed.), Realizing Utopia: The Future of International Law (Oxford University Press, 2012) 645-684, at 652-653.

${ }^{18}$ Recognized in L. Prosperi, J. Terrosi, 'Embracing the 'Human Factor': New Impetus at the ICC for Conceiving and Prioritising Intentional Environmental Harms as Crimes against Humanity?', in this special issue.

${ }^{19}$ Pues, supra note 12.

${ }^{20}$ Rosenberg, supra note 3.

${ }^{21}$ E. Cusato, 'Beyond Symbolism: Problems and Prospects with Prosecuting Environmental Destruction Before the ICC', in this special issue.

${ }^{22}$ N. Bernaz, 'An Analysis of the International Criminal Court Office of the Prosecutor's Policy Paper on Case Selection and Prioritization from the Perspective of Business and Human Rights', in this special issue.
} 